\title{
Niemann-Pick disease, type B with TRAP-positive storage cells and secondary sea blue histiocytosis
}

\author{
P. Sharma, R. Kar, S. Dutta, H.P. Pati, R. Saxena \\ Haematology Department, All India Institute of Medical Sciences, Ansari Nagar, New Delhi, India
}

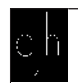

(C2009 European Journal of Histochemistry

We present 2 cases of Niemann Pick disease, type B with secondary sea-blue histiocytosis. Strikingly, in both cases the Pick cells were positive for tartrate resistant acid phosphatase, a finding hitherto described only in Gaucher cells. This report highlights the importance of this finding as a potential cytochemical diagnostic pitfall in the diagnosis of Niemann Pick disease.

Key words: Niemann pick disease, Gaucher disease, tartrate resistant acid phosphatase, sea blue histiocytosis.

Correspondence: Prashant Sharma,

Haematology Department, All India Institute of Medical Sciences, Ansari Nagar, New Delhi, India 110029.

Tel.: 91.11.26588500.

Fax: 91.11.26588663.

E-mail: prashant.sh@gmail.com

Paper accepted on June 5, 2009

European Journal of Histochemistry

2009; vol. 53 issue 3 (July-September): 183-186
W e present two unrelated patients who were referred to the Hematology OPD from Gastroenterology during work-up of longstanding splenomegaly 2 years apart and whose details are presented in Table 1. Neither had any neurological complaints or a history suggestive of developmental delay. Family history was negative for similar illness. Their bone marrows were examined when preliminary work-up for chronic haemolysis was negative and the hemograms revealed varying combinations of cytopenias. Liver and renal function tests were normal in both cases.

The marrow smears in both patients showed abundant classical Niemann Pick cells (foamy cytoplasm positive for the lipid stain Sudan black B, small central to eccentric nucleoli) with many seablue histiocytes, a well-recognized secondary phenomenon (Golde et al., 1975) (Figures 1 and 2). Diagnostic uncertainty arose when enzyme cytochemistry on the marrow smears showed intense tartrate resistant acid phosphatase (TRAP) activity in the foamy cells, periodic acid Schiff positive material and haemophagocytosis in the sea-blue histiocytes, findings hitherto described only in Gaucher cells (Weisberger et al., 2004) (Figures 3 and 4). No classical Gaucher cells were seen in multiple Romanowsky stained smears.

The diagnostic puzzle was resolved when both patients showed normal beta-glucocerebrosidase levels, very low levels of HDL cholesterol with low acid phosphatase, and in the one patient where it could be performed, a reduced but recordable level of sphingomyelinase activity (as seen in type B form), thus confirming clinico-pathologically the diagnosis of Niemann Pick disease, type B.

A literature search reveals that although serum TRAP levels may be mildly elevated in patients with Niemann Pick disease, the enzyme has not been localized cytochemically to these cells previously 


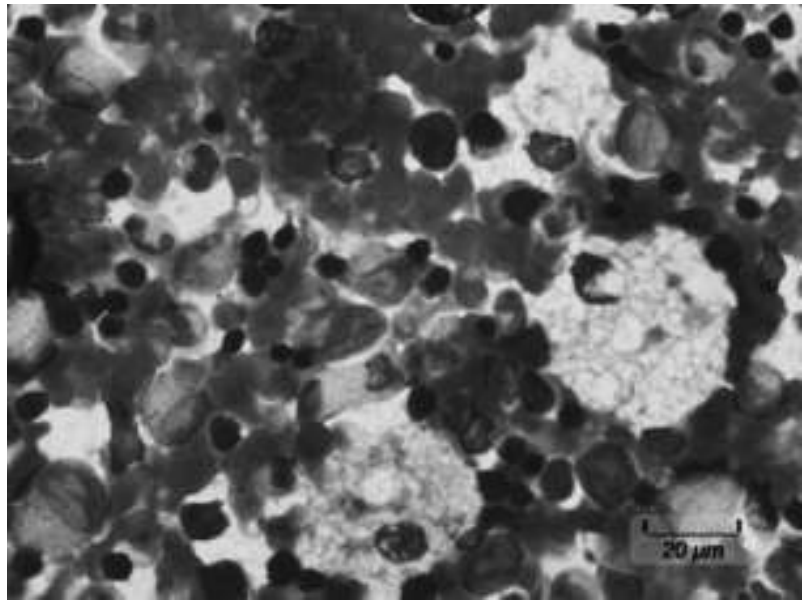

Figure 1. The bone marrow aspirate shows numerous Niemann Pick cells with abundant foamy cytoplasm and fewer and smaller sea-blue histiocytes (Jenner-Giemsa).

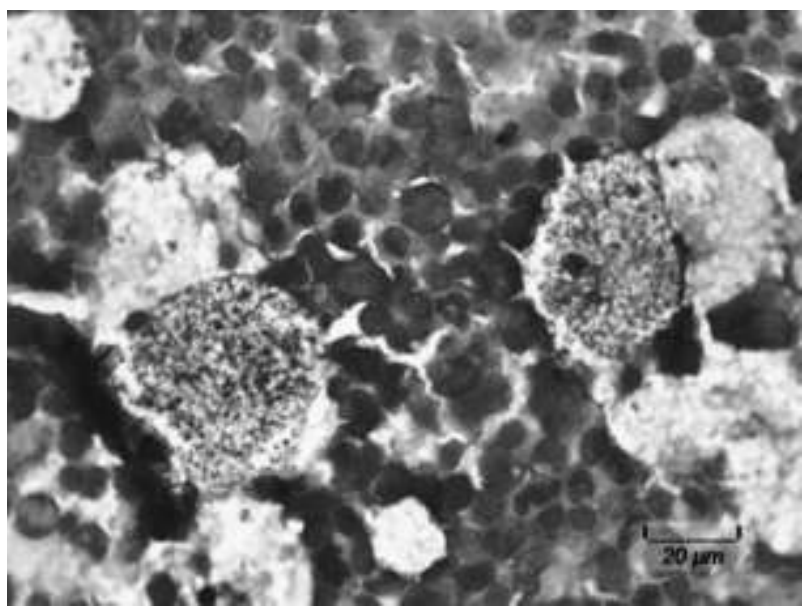

Figure 2. The multi-vacuolated Niemann Pick cells are positive for the lipid stain Sudan Black B. (Giemsa counterstaining).

(Chambers et al., 1977). Interestingly, a recent publication using sequence profiling and fold recognition methods suggests a remote evolutionary relationship between the phosphoesterase domain of acid sphingomyelinase (deficient in Niemann Pick disease) and purple acid phosphatases (mammalian form of which is TRAP) (Seto et al., 2004). The importance of this relationship is unclear but it is interesting to speculate whether there could be an upregulation of a related enzyme in face of congenital deficiency of acid sphingomyelinase in our cases. The iron content and the haemo-phagocytosis

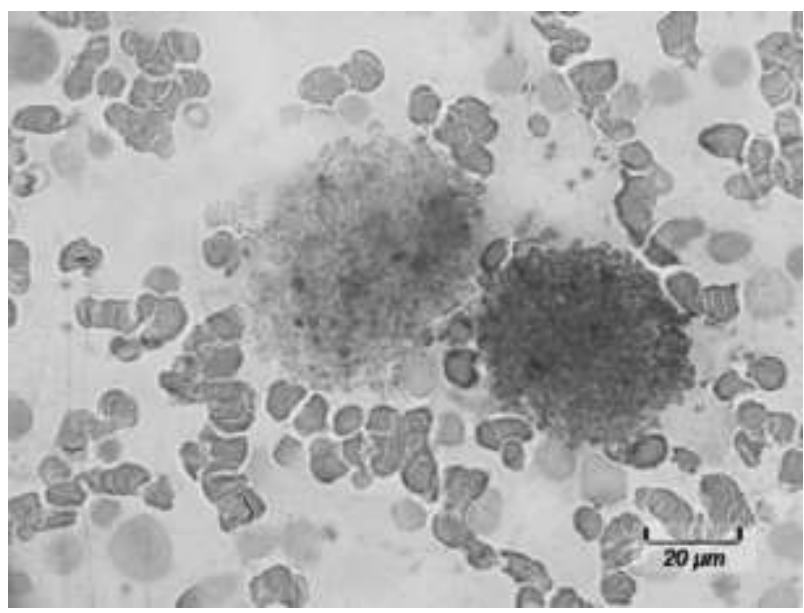

Figure 3. The Niemann Pick cells variably measure 20-50 micrometers in greatest diameter. They are uniformly and intensely positive for tartrate resistant acid phosphatase. (Methyl green counterstaining). The sea blue histiocytes' acid phosphatase is inhibited by tartaric acid (image not shown).

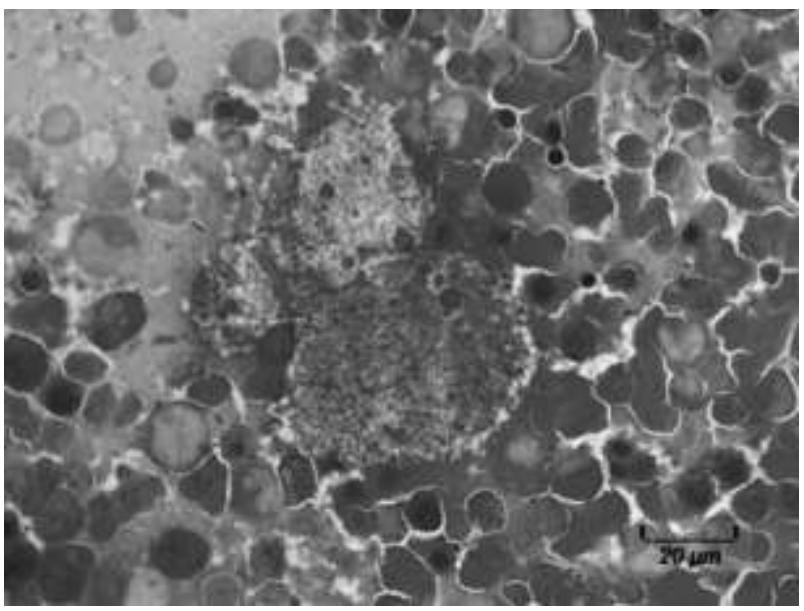

Figure 4. The Niemann Pick cells are only weakly positive for periodic acid Schiff stain. Gaucher cells would be expected to be brilliantly positive. (Haematoxylin counterstaining).

were possibly simply pointers towards the intrinsic histiocytic nature of the sea-blue histiocytes.

The major lesson from these cases is to alert the pathologist to the possibility of TRAP and iron positive histiocytic and storage cells other than Gaucher cells that may display haemophagocytosis. This is especially relevant to avoid incorrect diagnosis in resource-restricted settings in India where specialized diagnostic tests may be inaccessible or omitted if the morphological and cytochemical findings are felt to be characteristic of Gaucher disease. 
Table 1. Clinical, pathological and biochemical findings in the two patients.

\begin{tabular}{|c|c|c|}
\hline & Patient 1 & Patient 2 \\
\hline Age, sex & $14 \mathrm{yr} / \mathrm{F}$ & $18 \mathrm{yr} / \mathrm{F}$ \\
\hline Presenting complaints & $\begin{array}{l}\text { Pain, awareness of mass in left } \\
\text { upper abdomen } \times 12 \text { years }\end{array}$ & $\begin{array}{l}\text { Low grade fever on and off, abdominal discom } \\
\text { fort x } 2 \text { yrs }\end{array}$ \\
\hline $\mathrm{Hb}(\mathrm{gm} \%), \mathrm{TLC}(/ \mu \mathrm{L})$, platelets $(/ \mu \mathrm{L})$ & $7.3,4500,153000$ & $12,6900,47000$ \\
\hline Liver / Spleen & Not palpable / $14 \mathrm{~cm}$ below costal margin & Not palpable / massive enlargement (span 20 cm) \\
\hline Ultrasound abdomen & $\begin{array}{l}\text { Massive splenomegaly, multiple hyperechoeic } \\
\text { foci, no evidence of EHPVO or HVOTO }\end{array}$ & Splenomegaly, mesenteric lymphadenopathy \\
\hline CECT abdomen & Not done & $\begin{array}{l}\text { Splenomegaly, pre-aortic lymphadenopathy } \\
\text { (? lymphoma infiltration) }\end{array}$ \\
\hline $\begin{array}{l}\text { Serum bilirubin, alkaline phosphatase, SGOT, SGPT, } \\
\text { total protein, Albumin, urea, creatinine, sodium, potassium }\end{array}$ & Normal ranges & Normal ranges \\
\hline $\begin{array}{l}\text { Hemoglobin HPLC, direct and indirect antiglobulin tests, 24-hour } \\
\text { incubated osmotic fragility test, G6PD deficiency screening }\end{array}$ & Normal & Normal \\
\hline RK-39 antigen test for Leishmaniasis, HBsAg, anti HCV, anti HIV 1 \& 2 & Negative & Negative \\
\hline HDL Cholesterol (normal 40-50 mg\%) & 12 mg\% & $23 \mathrm{mg} \%$ \\
\hline Fundoscopic examination & Normal & Bilateral cherry red spots \\
\hline Acid phosphatase (normal >6.5 U/L) & $5.5 \mathrm{U} / \mathrm{L}$ & $4.2 \mathrm{U} / \mathrm{L}$ \\
\hline Bone marrow examination & $\begin{array}{l}\text { Aspirate: Cellular smears with normal marrow } \\
\text { elements, foamy histiocytes present along with } \\
\text { numerous sea blue histiocytes, some foamy } \\
\text { histiocytes show haemophagocytosis } \\
\text { Biopsy: hypercellular, foamy cells and other histiocytes } \\
\text { prominent }\end{array}$ & $\begin{array}{l}\text { Diluted marrow with many foamy } \\
\text { histiocytes and sea blue histiocytes, } \\
\text { normal marrow elements seen } \\
\text { Biopsy: normocellular, } \\
\text { foamy cells and other histiocytes present }\end{array}$ \\
\hline Cytochemistry & $\begin{array}{l}\text { Foamy cells positive for Sudan Black B, acid } \\
\text { phosphatase (AP), tartrate resistant acid } \\
\text { phosphatase (TRAP), weak hue with periodic acid } \\
\text { Schiff (PAS), sea blue histiocytes strongly positive } \\
\text { for PAS and AP }\end{array}$ & $\begin{array}{l}\text { Foamy cells positive for Sudan Black B, acid } \\
\text { Phosphatase, TRAP, weak positive with PAS; } \\
\text { sea blue histiocytes positive for PAS, AP }\end{array}$ \\
\hline Enzyme assay & $\begin{array}{l}\text { Normal beta-glucocerebrosidase level, } \\
\text { sphingomyelinase- not done }\end{array}$ & $\begin{array}{l}\text { Normal beta-glucocerebrosidase level, } \\
\text { sphingomyelinase- } 9 \mathrm{nmol} / 17 \mathrm{hr} / \mathrm{mg} \text { protein (normal } \\
10-47 \mathrm{nmol} / 17 \mathrm{hr} / \mathrm{mg} \text { protein) }\end{array}$ \\
\hline
\end{tabular}

\section{Acknowledgements}

We acknowledge gratefully the contributions of Mr. Nawal Prakash, Laboratory Technologist, Haematology Department, AIIMS in the expert cytochemical staining and Dr. Madhulika Kabra, Genetics Unit, Department of Paediatrics for the enzyme levels.

\section{References}

Chambers JP, Aquino L, Glew RH, Lee RE, McCafferty LR. Determination of serum acid phosphatase in Gaucher's disease using 4-methylumbelliferyl phosphate. Clin Chim Acta 1977;80:67-77.

Golde DW, Schneider EL, Bainton DF, Pentchev PG, Brady RO, Epstein $\mathrm{CJ}$, Cline MJ. Pathogenesis of one variant of sea-blue histiocytosis. Lab Invest 1975;33:371-8.

Seto $M$, Whitlow M, McCarrick MA, Srinivasan $S$, Zhu $Y$, Pagila $R$, et al. A model of the acid sphingomyelinase phosphoesterase domain based on its remote structural homolog purple acid phosphatase. Protein Sci 2004;13:3172-86.

Weisberger J, Emmons F, Gorczyca W. Cytochemical diagnosis of Gaucher's disease by iron stain. Br J Haematol 2004;124:696. 
P. Sharma, et al. 